\title{
Comparative responses of Glaucium spp. to salinity stress
}

\section{Abstract}

Salinity is considered as a major factor that reduces plant growth in arid and semiarid regions where soil salinity is naturally high, and precipitation is insufficient to achieve proper leaching. Plant species and cultivars within a species vary in their drought and salinity tolerance. These variations are associated with genes relating to stress tolerance mechanisms and their interaction with the environment. Horned Poppies (Glaucium spp.) are members of the Poppy family, Papaveraceae and are native to the Mediterranean and Middle East. The objectives of this study were to 1) evaluate the comparative salinity tolerance of Horned Poppy species, G. flavum, G. corniculatum, G. grandiflorum and G. acutidentatum, available from Denver Botanic Gardens; 2) examine the effects of salinity on plant characteristic associated with aesthetics of the species; and 3) determine tolerance mechanisms associated with superior salinity tolerance among tested species after evaluating the effects of salinity on total nonstructural carbohydrate content (TNC), shoot reducing sugar content (RSC), proline content and $\mathrm{K}+\mathrm{Na}+$ in shoots of Glaucium spp. Lysimeter columns were used in this study which was replicated twice in the CSU Plant science greenhouse. With increase higher salinity levels from tab water (control) to EC levels of 5,15, and $25 \mathrm{dSm}-1$, leaf color declined over time to unacceptable ratings (below 6). In G.flavum, leaf color was least affected under all salinity levels while all other species declined to the unacceptable rating of 5.3 (G. acutidentatum), 4 (G. grandiflorun), and 3.2 (G. corniculatum) at the salinity level of $25 \mathrm{dSm}-1$. Leaf area decreased linearly in all species with increasing salinity with a sharp drop at the salinity level of $25 \mathrm{dSm}-1$. G.flavum achieved the highest leaf area at all salinity levels followed by $\mathrm{G}$. acutidentatum, G.grandiflorum and G. corniculatum. The average leaf area of G.flavum when grown with tap water was $23 \mathrm{~cm} 2$ while the G. acutidentatum averge leaf area was $21.3 \mathrm{~cm}^{2}$. G.grandiflorum and G. corniculatum averge leaf area was $20.8 \mathrm{~cm} 2$ with tab water. G. flavum achieved an average height of $56 \mathrm{~cm}$ while $\mathrm{G}$. acutidentatum achieved an average height of $48 \mathrm{~cm}$ and G. grandiflorum had an average height of $35.1 \mathrm{~cm}$ in the control. G. corniculatum had the lowest height of $32.7 \mathrm{~cm}$ with the control treatment. In G. flavum, as salinity levels increased from control to 5,15 and $25 \mathrm{dS} \mathrm{m}-1$, average TNC

Abbreviations: EC, electrical conductivity; TNC, total nonstructural carbohydrate content; RSC, shoot reducing sugar content

\section{Introduction}

Salinity is considered the major factor that reduces plant growth in arid and semiarid regions where soil salinity is naturally high, and precipitation is insufficient to achieve proper leaching. Saline environments affect plant growth in different to include a reduction in water uptake, gradual accumulation of ions to toxic levels, and a reduction of nutrient accessibility. ${ }^{1}$ Increased use of brackish water and wastewater (effluent, recycled, or reclaimed water) has enhanced interest in the development of more salt tolerant landscape plants. ${ }^{2,3}$ The detrimental effects of salinity on plant growth include osmotic stress, ion toxicity, nutritional disturbances, ${ }^{5-6}$ damage to photosynthetic systems by excessive energy, ${ }^{7}$ and structural disorganization. ${ }^{8-10}$ Plants respond to salinity stress through a number of physiological changes including lowered leaf osmotic potential and/or a loss of turgor potential which can cause growth suppression. ${ }^{11}$ Salt tolerant plants often mediate stress by osmotic adjustment, therefore minimizing changes in turgor potential which affect plant growth responses linked to carbon dioxide assimilation and cell elongation. ${ }^{12}$
Volume 3 Issue 2 - 2019

\section{Ahmed O Getlawi, Mohamed A Shahba, Harrison G Hughes}

Department of Horticulture \& Landscape Architecture, USA

Correspondence: Department of Horticulture \& Landscape Architecture, Fort Collins, Colorado, 80523-I173, USA, Email shahbam@lamar.colostate.edu

Received: March 07, 2019 | Published: April 30, 2019

decreased by $15.7,28.6$ and $43.6 \%$ while the average TNC decrease in G. acutidenatum shoots was $17.6,36.8$ and $48 \%$. The decrease in G. grandflorum was 20, 40 and $48.6 \%$ while the decrease in G. corniculatum was $28.9,49$, and 53, respectively. As salinity levels increased from control to 5, 15 and 25 dS $\mathrm{m}-1$, average proline content in shoots increased by 218,367 , and $537 \%$ in G. flavum, 64.5, 296 and $510 \%$ in G. acutidenatum, 156, 273 and 428\% in G. grandflorum, and 79, 188 , and $337 \%$ in G. corniculatum, respectively. Results indicated that $\mathrm{K}+/ \mathrm{Na}+$ ratio was $\geq 1$ at all salinity levels in $\mathrm{G}$. flavum, as compared to G. acutidenatum, G. grandflorum and G. corniculatum. In conclusion, as salinity increased, Glaucium spp. exhibited reduction in leaf characteristics, plant height, flowering characteristics, overall plant quality (attractiveness), $\mathrm{TNC}$, and $\mathrm{K}+/ \mathrm{Na}+$ ratio, and increased shoot total reducing sugars and proline content. G. flavum showed higher salinity tolerance at all salinity levels as compared to the other species. Proline accumulation could add to the salinity tolerance through osmoregulation or by acting as a carbon and nitrogen sink for stress recovery.

Keywords: Horned Poppies, salinity tolerance, proline, glacium flavum, G corniculatum, G. grandiflorum and G. acutidentatum

Plant species and cultivars within a species vary in their drought and salinity tolerance. ${ }^{13-15}$ These variations are due to variations in genes relating to stress tolerance mechanisms and their interaction with the environments. ${ }^{16-19}$

Horned Poppies (Glaucium spp) are members of the Poppy family, Papaveracea and are native to the Mediterranean and Middle East regions. Some species have a wider distribution than others. Horned poppies require full sun and well-drained soils for optimum growth. They should be spaced between 30 and $60 \mathrm{~cm}$ apart when grown by direct seeding in the fall and thinning them in the spring to the desired spacing. For earlier bloom, seeds are sown indoors 8 to 10 weeks prior to planting and then transplanted into the garden after danger of frost has passed. Germination takes 8 to 15 days at 15 to $18^{\circ} \mathrm{C}$. Seedlings should be transplanted to individual pots when three leaves have formed but before the taproot has developed. Transplanting should be done without disturbing the root system. The crinkly, gray-green leaves also appear on the stems and below each flower. All horned poppies have blue-green foliage that is deeply pinnatified to pinnatisect and typically grow $30-50 \mathrm{~cm}$ long. The leaves have varying degrees of texture from glaucous to villous. All leaves are lyrate to sub-lyrate shaped and have a rosette growth habit. They have solitary blooms on flower stalks that grow above the foliage. All species have four petals in their corolla and their pistil is surrounded 
by stamens. They all develop long horned-shaped seed siliquiforms with the stigma remaining to cap off the top of the fruit. Species of interest in this study are G. flavum, G. grandiflorum, G. acutidentatum and G. corniculatum.

G. flavum Crantz is the most widely spread species in the genus. It's found in the coasts of Britain and the Atlantic Islands to the coasts of the Mediterranean Basin and the Black Sea. ${ }^{20}$ It grows predominantly on sandy beaches and as a result it is commonly known as the Sea Horned Poppy. This likely indicates that G. flavum is salt tolerant. According to Davis, ${ }^{21} \mathrm{G}$. flavum is distinguished from other species by several characteristics. The sepals have crisp, pilose hairs on the surface and the petals can be solid yellow, red or reddish mauve. G. flavum is most often recognized for the yellow petals and is commonly referred to as the Yellow Horned Poppy. The ovary is densely papillose to tuberculate, basically a bumpy surface. The siliquae will retain the papillose to tuberculate texture. In Turkey, G. flavum normally flowers from May through the summer and even though it is most often found at sea level, it does grow into river valleys as well. ${ }^{21}$

G. grandiflorum Boiss \& É. Huet is native to Turkey in the southern part of the Caucasus Mountains but it is also found in Syria, Iran and the Sinai. ${ }^{20}$ Turkey is situated between the Mediterranean Sea and the Black Sea, where the precipitation ranges from 580 to 1300 $\mathrm{mm} /$ year. However, in the mountain ranges of the country there are variable climate conditions with harsh winters and drier conditions with a low precipitation of $400 \mathrm{~mm} /$ year. G. grandiflorum has features that distinguish it from other Glaucium species. It has only one main flower stem while other species have multiple flower stalks growing from the base of the rosette. ${ }^{21}$ The sepals have short, stiff hairs making the surface hirsute. The petals are dark orange to crimson red with a black spot at the base of the petal. The pedicle of the flower exceeds the subtending leaf, which differs from the other Glaucium species. There are two varieties of G. grandiflorum: var. grandiflorum and var. torquatum. G. grandiflorum var. torquatum has red petals with a black blotch and can be found in calcareous hillsides. G. grandiflorum var. grandiflorum is found in fields, banks and rocky slopes.

G. acutidentatum Hausskn \& Bornm is endemic to Turkey where it is found on dry hillslopes and rocky places. ${ }^{20} \mathrm{G}$. acutidentatum is the most glabrous species with smooth sepals and ovaries. Although the ovary is smooth, the resulting siliquae is subtorulose. The petals are solid orange-buff in color. G. acutidentatum is found at elevations of 950-1400 m on dry hills. ${ }^{21}$

G. corniculatum (L.) J.H. Rudolph is native to the Mediterranean basin, Atlantic islands, Caucasus Mountains, Bulgaria, Romania, northern Iraq and northwestern Iran. ${ }^{20,21}$ G. corniculatum also has some unique characteristics. Its leaves have a soft, villous texture and its sepals are scabrous to hirsute. There is some conflicting information about G. corniculatum's corolla. The petals are yellow, orange or red $^{21}$ with a black basal spot. ${ }^{20}$

The balance between carbohydrate production and consumption will impact the ability of a plant species to cope with salinity stress. ${ }^{22-24}$ The decline in salinity tolerance in some species can be associated with reduced carbohydrate availability and reduced effectiveness of $\mathrm{Na}+$ exclusion and $\mathrm{K}+$ active uptake and transport. ${ }^{25-28}$

Proline accumulates in larger amounts than other amino acids in salt stressed plants. ${ }^{24}$ Proline accumulation is the first response of plants exposed to salt stress and water-deficit stress and is thought to reduce injury to cells. ${ }^{29}$ Maggio et al..$^{30}$ suggested that proline may act as a signaling/regulatory molecule able to activate multiple responses that participate in the adaptation process to elevated salinity levels. Rapid accumulation of proline in tissues of many plant species in response to salt, drought or temperature stress has been attributed to enzyme stabilization and/or osmoregulation. ${ }^{11,31}$ Ahmad et al. ${ }^{32}$ measured Proline content fluctuations under high salinity levels in salt tolerant and sensitive ecotypes of creeping bentgrass (Agrostis stolonifera L.) and concluded that the salt tolerant ecotype accumulated more proline in response to high salinity levels. Lee et al. ${ }^{24}$ concluded that proline was the primary organic osmolyte for osmotic adjustment and proline accumulation was higher in salt tolerant seashore paspalum genotypes. However, other reports have indicated a negative effect of proline on salinity tolerance. Marcum (2002) has reported that proline accumulates in grasses under salinity stress at insufficient levels to achieve osmotic adjustment. Torello and Rice ${ }^{33}$ concluded that Proline accumulation has no significant osmoregulatory role in salt tolerance of five turfgrass species ['Fults' alkaligrass (Puccinellia distans L. Parl.), 'Dawson' red fescue (Festuca rubra L. vat trichophylla Gaud.), 'Jamestown' red fescue (Festuca rubra L. vat commutata Gaud.), 'Adelphi' and 'Ram I' Kentucky bluegrass (Poa pratensis L.)] following their exposure to $170 \mathrm{mM} \mathrm{NaC} 1$ salinity stress. Because of these contrasting reports on the role of proline in salt tolerance, its use as a selection criterion for salt tolerance has been questioned. ${ }^{34}$ Thus, proper testing is required before making any conclusion regarding proline role in salinity tolerance in specific species.

The objectives of this study were to

1. Evaluate the comparative salinity tolerance of the common Horned Poppy species, G. flavum, G. corniculatum, G. grandiflorum and G. acutidentatums;

2. Examine the effects of salinity on plant characteristic that are associate with the aesthetics of Horned Popy; and

3. Determine which tolerance mechanism is associated with superior salinity tolerance among the tested species.

\section{Materials and methods}

Lysimeter columns were used in this study which was replicated twice. All columns were placed in CSU, Plant Science greenhouse, Fort Collins, Co. Glaucium spp. plants were grown from seeds planted in potting mix, (Pro-Mix, Mycorrhizae and Biofunglcide). Fifty seedlings, at the 3-leaf stage, of each species were transplanted one per PVS tubes (15 cm diameter and $50 \mathrm{~cm}$ long) containing commercial potting mix, (Pro-Mix, Mycorrhizae and Biofunglcide). The plants were maintained under greenhouse conditions in the PVC tubes until full establishment and recovery from transplanting. The experimental design was a randomized complete Block (RCB). Each block represented one of the studied species and contained 16 tubes. Seedlings used in the expermiments were chosen based on their similarity in size and number of leaves. Salinity treatments were control (Tap water), $\mathrm{EC}=5, \mathrm{EC}=15$ and $\mathrm{EC}=25 \mathrm{dSm}-1$. Saline solutions were prepared using instant ocean salt mixture added to the irrigation water. Treatments were replicated four times. Salinity treatments were imposed after seedlings were fully established after transplanting. Soil leachate was collected biweekly to measure its EC, and adjustments were made as needed. Water use by the plants was measured weekly. Two tubes of each species were used as Lysimeter columns to monitor the weekly change in the evapotranspiration and the treatment amount adjusted accordingly. These tubes were watered with excess water, left to drain for $2 \mathrm{~h}$, and the weight of each tube was recorded. Each tube was then re-weighed $24 \mathrm{~h}$ later. Over the course 
of the experiments data were collected weekly on plant height, leaf color, leaf area, number of flower buds, size and number of flowers, quality and general aesthetics of the plants. Samples were collected for TNC, RSC, proline and tissue $\mathrm{Na}+$ and $\mathrm{K}+$ content analysis for each treatment. Visual quality was rated biweekly based on color, flower buds, flower number and size, height and uniformity using a scale of 0 (not attractive) to 10 (optimum attractiveness).

Total nonstructural carbohydrate content, RSC, tissue $\mathrm{Na}+$ and $\mathrm{K}+$ and proline content were determined at the termination of the experiment. Shoot tissue at the termination of the experiment was harvested and washed with cold distilled water to remove plant debris for carbohydrate analysis. Approximately $5 \mathrm{~g}$ samples from the treatments were freeze-dried (Genesis 25 LL Lyophilizer, Virtis, Gardiner, NY). After freeze-drying, samples were ground with a Wiley mill, sieved thought a screen with $425 \mu \mathrm{m}$ openings, and kept in airtight vials at-20 oC. TNC was measured using the method described by Chatterton et al. ${ }^{35} \mathrm{In}$ brief, $25 \mathrm{mg}$ freeze-dried samples were transferred to $5 \mathrm{ml}$ of $0.1 \%$ clarase solution and incubated at $38^{\circ} \mathrm{C}$ for $24 \mathrm{~h}$. Then, $0.5 \mathrm{ml}$ of hydrochloric acid $(50 \%$, v/v) was added to the incubation solution. After the solution was incubated at room temperature for $18 \mathrm{~h}$, the $\mathrm{pH}$ value of the solution was adjusted to between 5 and 7 with 10 and $1 \mathrm{~N} \mathrm{NaOH}$. This resulting solution was used to determine TNC content using a spectrophotometer at $515 \mathrm{~nm}$ wavelength (model DU640; Beckman).

To measure the free reducing sugar, $25 \mathrm{mg}$ of the freeze dried, ground, and sieved sample was extracted with $10 \mathrm{ml}$ of $0.1 \mathrm{M}$ phosphate buffer $(\mathrm{pH}=5.4)$ for $24 \mathrm{~h}$ at room temperature. An extracted aliquot $(0.2 \mathrm{~mL})$ was used to determine the reducing sugar content by using the same method as was used to measure TNC.

To measure ion content, about $5 \mathrm{~g}$ of shoots were harvested, washed with deionized water, and dried at $70^{\circ} \mathrm{C}$ for $24 \mathrm{~h}$. Dried shoots were ground in a Wiley mill and passed through a screen with $425 \mu \mathrm{m}$ openings. Approximately $1 \mathrm{~g}$ of dried and screened sample was weighed and ashed for $7 \mathrm{~h}$ at $500^{\circ} \mathrm{C}$. Ash was dissolved in 10 $\mathrm{ml}$ of $1 \mathrm{~N} \mathrm{HCl}$ and diluted with deionized water. Solution aliquots were analyzed for $\mathrm{Na}+$ and $\mathrm{K}+$ by inductively-coupled plasma atomic emission spectrophotometry (ICP-AES) (Model 975 plasma Atomcomp, Thermo Jarrell Ash Corp., Franklin, Mass.)

Actual proline tissue accumulation levels were determined according to the method of Bates et al. ${ }^{36}$ as modified by Torello and Rice $^{33}$ with approximately $0.5 \mathrm{~g}$ fresh weight of tissue. Samples were ground with liquid nitrogen in a mortar. Each sample was homogenized in $10 \mathrm{ml}$ of $3 \%$ aqueous sulfosalicylic acid followed by agitation for $1 \mathrm{~h}$ prior to filtration through \#2 Whatman filter paper. After filtration $2 \mathrm{ml}$ of extract from each sample was reacted with $2 \mathrm{ml}$ of ninhydrin reagent $(1.25 \mathrm{mg}$ of ninhydrin in $30 \mathrm{~mL}$ of glacial acetic acid and 20 $\mathrm{mL}$ of $6 \mathrm{M} \mathrm{H3PO} 4)$ and $2 \mathrm{ml}$ of glacial acetic acid followed by $1 \mathrm{~h}$ of heating at $100^{\circ} \mathrm{C}$ in an enclosed water bath. Samples were then quickly cooled by immersion in an ice bath and total proline was determined spectrophotometrically at $520 \mathrm{~nm}$. Actual proline tissue accumulation levels were determined by subtracting mean control data from salinity treatment data for all cultivars during the entire experimental period.

\section{Data analysis}

The data of the two experiments were subjected to ANOVA to test the experiment effect and the interaction between treatments and experiments. The experimental run was not significant. Therefore, data were pooled over experiments to test the effects of salinity, species and their interactions using ANOVA. ${ }^{37}$ Leaf characteristics (color and area), number of buds, and flower characteristics (number and size) were analyzed on individual measurement dates to examine salinity, and species effects over time. Means were separated by least significant difference at the 0.05 level of probability. Regression analysis was performed to determine the relationship between the measured parameters at the end of the study (dependent variables) and the salinity levels (independent variable).

\section{Results and discussion}

\section{Leaf characteristics}

Leaf color. Comparisons of leaf color among species and salinity levels clearly showed significant differences (Table 1). With higher salinity, leaf color declined over time to unacceptable ratings (below 6). In G. flavum, leaf color was not as adversely affected under all salinity levels as all other species which declined to the unacceptable rating of 5.3 (G. acutidentatum), 4 (G. grandiflorun), and 3.2 (G. corniculatum) at the salinity level of $25 \mathrm{dSm}-1$ (Figure 1). Leaf data from other species showed similar responses to the increasing salinity.

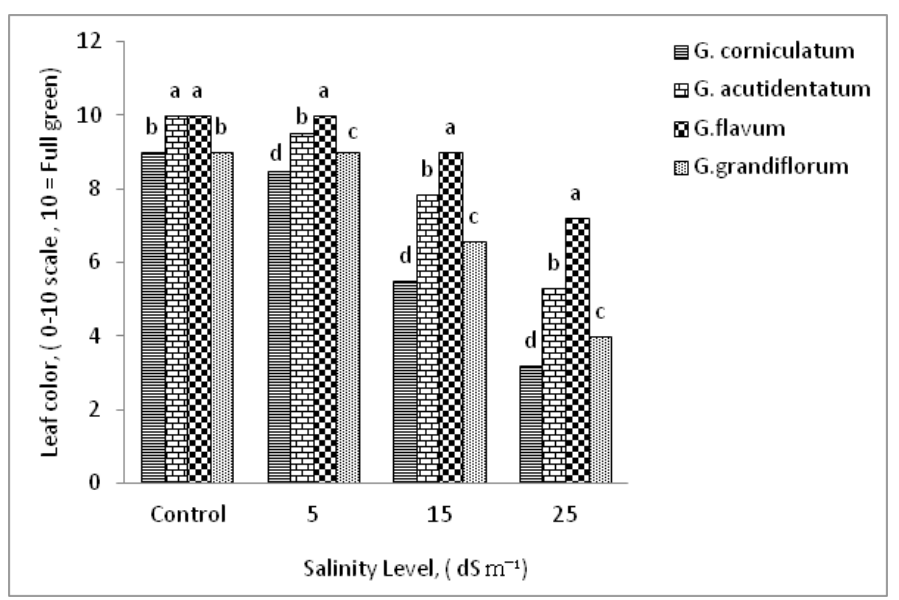

Figure I Effect of different salinity levels on leaf color of four Glaucium spp. Columns labeled with different letters are significantly different at $\mathrm{P}=0.05$ within each salinity level.

Bayat et al. ${ }^{38}$ found a $61 \%$ decrease in chlorophyll index as a result of $300 \mathrm{mM} \mathrm{NaCl}$ in Persian petunia. ${ }^{38}$ The upper leaves of butterhead lettuce had a dark-green color, while lower leaves showed chlorosis under high salinity. ${ }^{39}$ It seemed that salinity targeted chlorophyll formation processes which resulted in pale or yellow leaves. ${ }^{40}$ High level of salinization decreases the content of pigment fractions (chlorophyll a and b) through the suppression of the enzymes that are associated with the synthesis of photosynthetic pigments. ${ }^{11,41,42}$ Salt stress opens porphyrin rings and through fusion, harmful solutes are transferred to the vacuole. The presence of these solutes results in the loss of the green color of leaves ${ }^{43}$ and ultimately reduces the chlorophyll concentration in the leaf. ${ }^{44-46}$ The interference of salt ions on the newly synthesized protein molecules has another negative effect on the chlorophyll biosynthesis. ${ }^{42}$ Salinity affects turfgrasses and other landscape plant by reducing their value. ${ }^{47-52}$

Leaf area. Analysis of variance indicated significant differences among species and among salinity levels and their interactions (Table 1). Linear regression indicated a significant negative association between leaf area and salinity levels (Table 2). Leaf area decreased linearly in all species with increasing salinity with a sharp drop at the 
salinity level of $25 \mathrm{dS}$ m-1. G. flavum achieved the highest leaf area at all salinity levels followed by G. acutidentatum, G. grandiflorum and G. corniculatum. G. flavum achieved an average leaf area of 23 $\mathrm{cm}^{2}$ while G. acutidentatum achieved an averge leaf area of $21.3 \mathrm{~cm}^{2}$ and with both G. grandiflorum and G. corniculatum with a leaf area of $20.8 \mathrm{~cm} 2$ in the control treatment (Figure 2). Leaf area decreased from 23 to $20,17.6$ and $10.8 \mathrm{~cm}^{2}$ in G. flavum, from 21.3 to 18.8 , 14.3 , and $8.2 \mathrm{~cm}^{2}$ in G. acutidentatum, from 20.8 to18.2, 11.8, and $6 \mathrm{~cm}^{2}$ in G. grandiflorum, and from 20.8 to $18.1,10.9$, and $4.5 \mathrm{~cm}^{2}$ in G. corniculatum when the salinity increased from the control to 5,15 and $25 \mathrm{dSm}-1$, respectively (Figure 2). Leaf area followed the similar trend of leaf color since healthy leaves generally have a greater leaf area. Previous reports indicated similar salinity effect on leaf area $^{53}$ in other species. Continuous exposure to elevated root-zone salinity progressively decreased leaf size over time. ${ }^{54,55}$
The decline in leaf growth was the earliest response of exposure to salinity stress. ${ }^{56,57}$ Plants cope with salinity stress by decreasing their leaf area to conserve energy. ${ }^{42}$ Leaf area decreased gradually with increasing salinity in Withania somnifera under salt stress, ${ }^{42}$ and in Salvodora persica. ${ }^{42,58}$ Salinities above $25 \mathrm{mM}$ resulted in a decrease in leaf area in mangrove species ${ }^{59}$ as well. In aquatic plants, high salinity or a prolonged exposure to salt causes greater leaf mortality than leaf gain per plant and eventual death. ${ }^{60-62}$ This may be a direct effect of salt on rate of cell division, to a slower rate of cell expansion, or a decrease in the duration of cell expansion. If cell division was affected, even if cell growth potential was not affected, final leaf size would be limited due to reduced cell number. ${ }^{55}$ The rapid response to the increase in salinity is mainly osmotic and resulted in inhibition of leave formation. The long-term response is a result of ionic toxicity that accelerates senescence of mature leaves. ${ }^{63}$

Table I Analysis of variances with mean square and treatment significance of leaf color, leaf area, plant height, number of buds, number of flowers, flower are, plant quality (attractiveness), total non-structure carbohydrate content (TNC), shoot reducing sugar content (RSC), Proline content and shoot $\mathrm{K}+/ \mathrm{Na}+$ ratio in Glaucium spp

\begin{tabular}{|c|c|c|c|}
\hline \multirow{2}{*}{ Parameters } & \multicolumn{3}{|l|}{ Source } \\
\hline & Species (S) & Salinity (EC) & SXEC \\
\hline Leaf color (0-10 scale) & $9.2^{* *}$ & $75.5^{* *}$ & $69.5 *$ \\
\hline Leaf area $\left(\mathrm{cm}^{2}\right)$ & $2.3^{* *}$ & $3.44 * *$ & $2.2^{*}$ \\
\hline Plant height $(\mathrm{cm})$ & $4.42 * *$ & $3.88 * *$ & $3.25 *$ \\
\hline Number of buds & $39.7 * *$ & $88.0 * *$ & $29.4^{*}$ \\
\hline Number of flowers & $4.4^{* *}$ & $7.9 * *$ & $3.9 *$ \\
\hline Flower area $\left(\mathrm{cm}^{2}\right)$ & $2.9 * *$ & $1.7 * *$ & $3.7^{*}$ \\
\hline Plant quality (0-10 scale) & $9.5^{* * *}$ & $8.6 * *$ & $6.1 *$ \\
\hline $\mathrm{K}^{+} / \mathrm{Na}^{+}$ & $139.0 * *$ & $54.0 * *$ & $299.0^{*}$ \\
\hline TNC (mgg-1 dry wt) & $1690 * *$ & $|77|^{* *}$ & $2895^{*}$ \\
\hline RSC (mgg-1 dry wt) & $47.0 * *$ & $892.0 * *$ & $521.0^{*}$ \\
\hline Proline content ( $\mu g g^{-1}$ fresh wt.) & $1870 * *$ & $2997 * *$ & $1897^{*}$ \\
\hline
\end{tabular}

*Significant at $P \leq 0.05$.

$* *$ Significant at $P \leq 0.01$.

Table 2 Linear regression of different parameters of Glaucium spp. measured at the end of the experiment vs. salinity levels, Control (c), 5, $15,25 \mathrm{dSm}{ }^{-1}$

\begin{tabular}{|c|c|c|c|c|c|c|}
\hline \multirow{3}{*}{ Species } & \multicolumn{6}{|l|}{ Parameter } \\
\hline & \multicolumn{2}{|c|}{ Plant quality (0-10 scale) } & \multicolumn{2}{|l|}{ Leaf area $\left(\mathrm{cm}^{2}\right)$} & \multicolumn{2}{|c|}{ Flower area $\left(\mathrm{cm}^{2}\right)$} \\
\hline & Regression & $\mathbf{R}^{2}$ & Regression & $\mathbf{R}^{2}$ & Regression & $\mathbf{R}^{2}$ \\
\hline G. acutidentatum & $Y=6.20-0.22 X$ & $0.84 * *$ & $Y=122.5-1.22 X$ & $0.88 * *$ & $Y=320.5-7.1 X$ & $0.80 * *$ \\
\hline G. corniculatum & $Y=5.06-0.33 X$ & $0.68^{*}$ & $Y=|3| .2-1.16 X$ & $0.89 * *$ & $Y=303.3-2.8 X$ & $0.75^{*}$ \\
\hline G. flavum & $Y=8.6-0.16 X$ & $0.92 * *$ & $Y=122.8-1.32 X$ & $0.83 * *$ & $Y=313.3-0.8 X$ & $0.94 * *$ \\
\hline G. grandiflorum & $Y=2.92-0.18 X$ & $0.85 * *$ & $Y=133.2-1.55 X$ & $0.75^{*}$ & $Y=299.0-8.8 X$ & $0.77^{*}$ \\
\hline
\end{tabular}

*Significant at $P \leq 0.05$.

**Significant at $P \leq 0.01$.

\section{Plant height}

Generally, there was a significant decrease in plant height as salinity increased. As salinity increased there were significant differences among the species in plant height (Table 1). G. flavum achieved an average height of $56 \mathrm{~cm}$ while $\mathrm{G}$. acutidentatum averaged $48 \mathrm{~cm}$ and G. grandiflorum had an average height of $35.1 \mathrm{~cm}$. G. corniculatum was the shortest with an average height of $32.7 \mathrm{~cm}$ in the control treatment (Figure 3). Plant height decreased from 55.5 to 51.6, 35.4 and $29.9 \mathrm{~cm}$ in G. flavum, from 47.7 to $38.4,26.7$, and $16.7 \mathrm{~cm}$ in G. acutidentatum, from 35.1 to $28.5,6.3$, and $5.8 \mathrm{~cm}$ in G.grandiflorum, and from 32.7 to $27.3,5.3$, and $4.5 \mathrm{~cm}$ in G. corniculatum as the salinity level increased from the control to 5,15 and $25 \mathrm{dS} \mathrm{m}-1$, respectively (Figure 3). By comparing the decrease in plant height 
under the salinity level of $25.0 \mathrm{dS} \mathrm{m}-1$ to the corresponding control treatment, the decrease in plant height in G. flavum was 7, 36 and $46 \%$ while was $19.7,44$ and $65 \%$ in G. acutidentatum. The decrease was 19,82 and $83 \%$ in G. grandiflorum and $16.5,83.8$, and $86 \%$ in G. corniculatum at 5, 15 and $25 \mathrm{dSm}-1$, respectively (Figure 3). Several reports have demonstrated the negative effects of salinity on plant height ${ }^{1,4,57,64-66}$ in various plant species. Studies on Brassica have shown severe reduction in plant height due to salinity. ${ }^{1}$ In Brassica, increasing salinity levels from 0 to $12 \mathrm{dSm}-1$ resulted in reduction in plant height from $68.68 \mathrm{~cm}$ to $50.66 \mathrm{~cm}$. Also, there were significant differences among Brassica genotypes in their response to salinity. ${ }^{1}$ Similarly, significant variations of impact of increasing salinity were reported for rapeseed cultivars including interaction of salinitycultivars for plant height. ${ }^{1,66}$ The reduction in growth parameters such as height could be attributed to several effects such as the osmotic stress and /or ionic toxicity ${ }^{4}$ which is more harmful to plants during the succulent seedling stage in addition to the stressful effects of ion uptake ${ }^{67,57}$ Salinity stress favors the growth of roots rather than shoots which results in a decrease in plant height. Marcum ${ }^{68}$ reported root mass increased under saline conditions of several grasses at mowing heights ranging from 35 to $75 \mathrm{~mm}$. Also, root growth stimulation under saline conditions has been reported in several salinity tolerant grasses as well. ${ }^{49,69} \mathrm{Fu}$ et al. ${ }^{47}$ found an increase in total root mass ranging from $30 \%$ to $66 \%$ and $39 \%$ to $89 \%$ at the 25.4 mowing height as compared to 12.7 and $6.4 \mathrm{~mm}$ mowing heights, respectively when salinity was between the control level and $10 \mathrm{dS} \mathrm{m}-1$. Shahba ${ }^{27}$ and Shahba et al. ${ }^{28}$ reported an increase in root mass of Bermuda grass cultivars and seashore paspalum cultivars when salinity level increased from control to $20.0 \mathrm{dS}$ m-1. Rozema and Visser ${ }^{70}$ indicated that increased rooting and the associated increase in root absorbing area is an adaptive mechanism to the osmotic and nutrient deficiency stresses occurs under saline conditions with the result of a reduction in shoot mass and plant height. Unfortunately, we have not measured the change in root mass in this study to assure this effect in Glaucium spp.

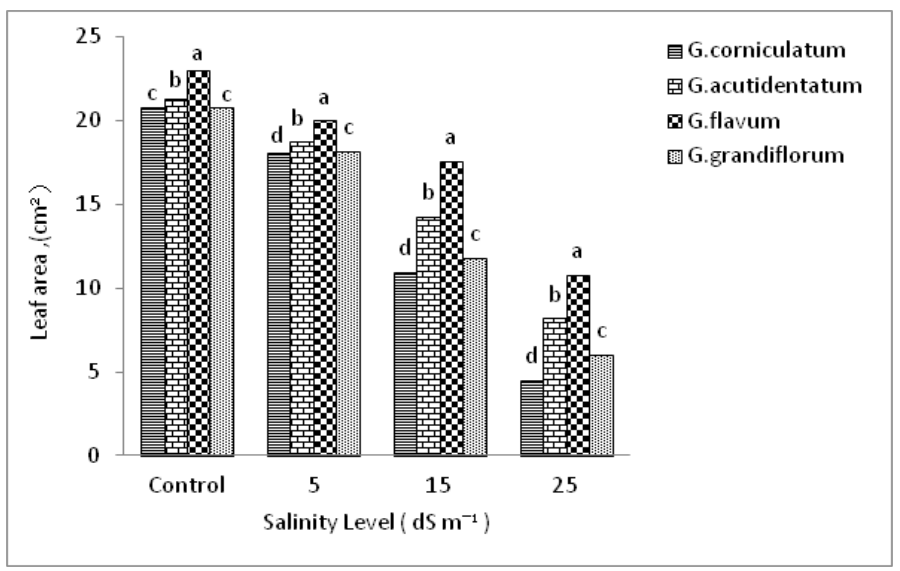

Figure 2 Effect of different Salinity levels on leaf area of four Glaucium spp. Columns labeled with different letters are significantly different at $\mathrm{P}=0.05$ within each salinity level.

\section{Flowering characteristics}

Number of flower buds. Numbers of flower buds varied significantly among Glaucium spp., salinity levels and their interaction (Table 1). Increased salinity levels resulted in fewer flower buds (Figure 4). In G. flavum, as salinity levels increased from control to 5,15 and $25.0 \mathrm{dS} \mathrm{m}-1$ average buds number decreased by $11.5,36$ and $65 \%$ respectively. The decrease was greater in G. acutidentatum where the average number of flower buds decreased by 36,60 and $79 \%$ when salinity increased from control to 5, 15 and $25 \mathrm{dSm}-1$, respectively. G. grandiflorum and G. corniculatum did not produce any flower buds at the salinity levels of 15 and $25 \mathrm{dS} \mathrm{m}-1$. This study showed that salinity significantly affected the production of flower buds. At the control treatment, all species produced flower buds wih the highest number produced by G. flavum (30.5), followed by G. acutidentatum (29), G.grandiflorum (11) and the lowest number of flower buds was produced by G. corniculatum (10) (Figure 4).

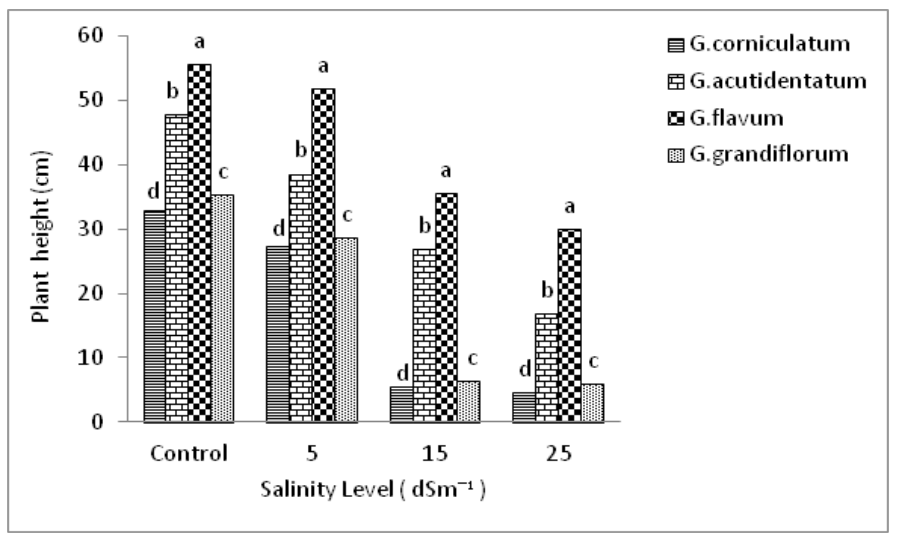

Figure 3 Effect of different Salinity levels on the height of four Glaucium spp. Columns labeled with different letters are significantly different at $\mathrm{P}=0.05$ within each salinity level.

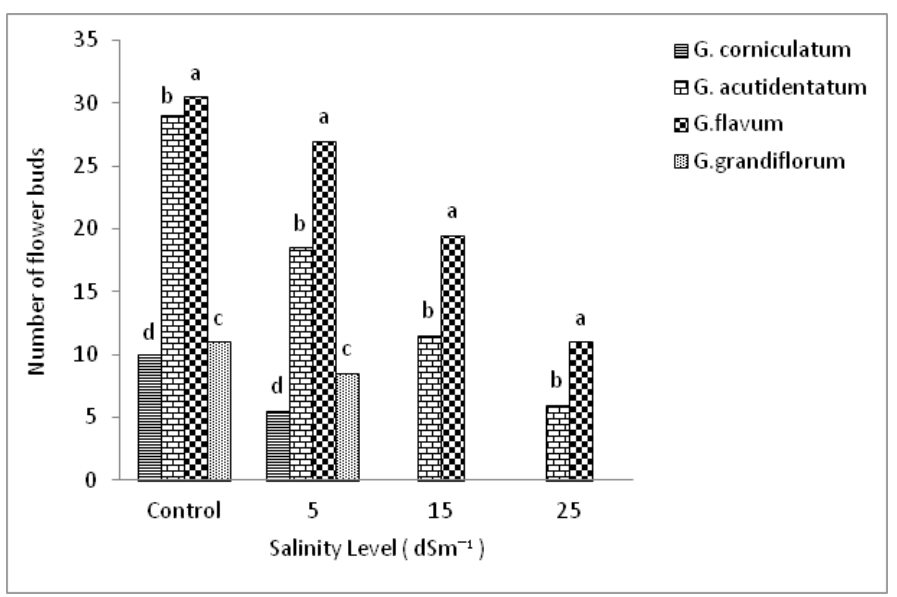

Figure 4 Effect of different Salinity levels on number of flower buds of four Glaucium spp. Columns labeled with different letters are significantly different at $\mathrm{P}=0.05$ within each salinity level.

Number of flowers. The number of actual flowers is another indicator of plant vigor. Number of flowers varied significantly $(\mathrm{P}<0.05)$ among species, salinity levels and their interaction (Table 1). The number of flowers declined with higher salinity. The decline in flower number under higher salinity was more severe and more rapid in less salinity tolerant species (G. grandiflorum and G. corniculatum) and was moderate in G. flavum and G. acutidentatum (Figure 5). G. flavum produced the greatest number of flower under all salinity levels when compared to the other species (Figure 5). G. corniculatum had the lowest number of flowers at all salinity levels. G. flavum (28.5) had the greatest number of flowers in the control treatment followed by G. acutidentatum (24), G. grandiflorum (9) and G. corniculatum 
(8.2) in average. Only G. flavum and G. acutidentatum developed at the salinity levels of 15 and $25 \mathrm{dSm}-1$ (Figure 5). Flower area. Comparisons of flower area among species and among salinity levels and their interaction clearly showed significant differences (Table 1). Flower area decreased linearly with increasing salinity level. Regressions were strongly linear, with slope more negative with less tolerant species (Table 2). At the control treatment, flower area was the greatest in G. flavum $\left(23 \mathrm{~cm}^{2}\right)$ followed by $\mathrm{G}$. acutidentatum $\left(17 \mathrm{~cm}^{2}\right)$, and G. grandiflorum $\left(10.5 \mathrm{~cm}^{2}\right)$. G. corniculatum had the smallest total flower area at the control treatment $\left(8.9 \mathrm{~cm}^{2}\right)$. The decline in flower area under higher salinity was more severe and more rapid in species (G. grandiflorum and G. corniculatum) that were less tolerant to salinity and was moderate in G. flavum and G. acutidentatum (Figure 6). G. flavum showed greater flower area under all salinity levels compared to other species (Figure 6).

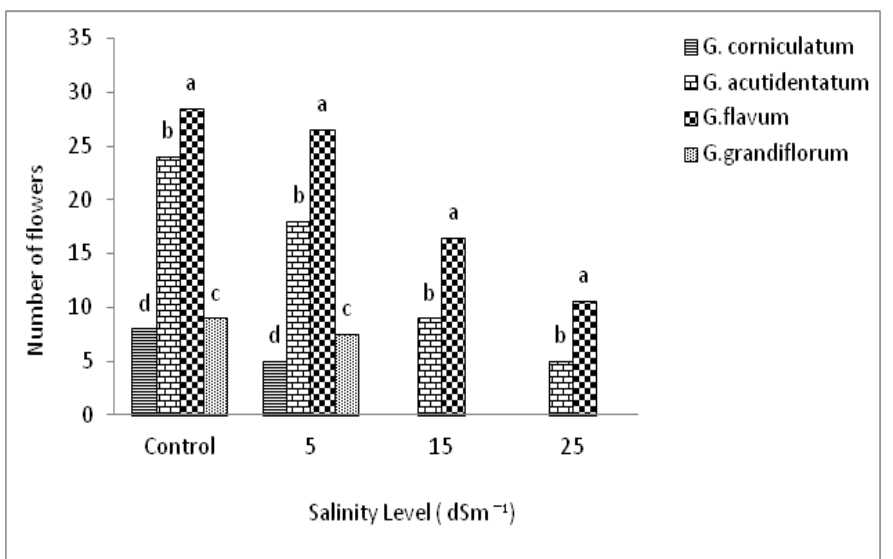

Figure 5 Effect of different Salinity levels on the number of flowers of four Glaucium spp. Columns labeled within different letters are significantly different at $\mathrm{P}=0.05$ within each salinity level

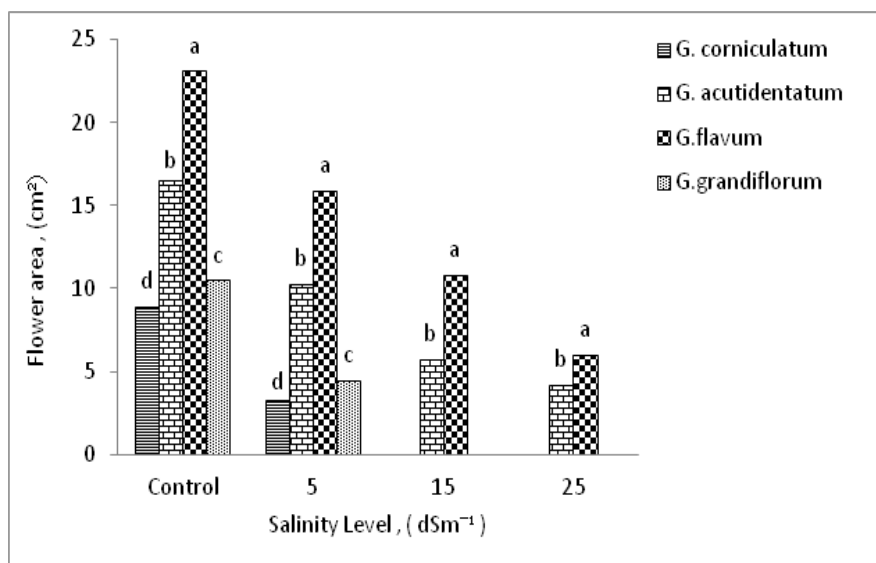

Figure 6 Effect of different Salinity levels on flower area of four Glaucium spp. Columns labeled with different letters are significantly different at $\mathrm{P}=0.05$ within each salinity level.

The results are similar to several previous reports in other species. Soil salinity resulted in significant flower bud mortality in blueberry ${ }^{71}$ while Falcon et al..$^{72}$ reported a continuous yield reduction of rose as salinity increase. Küçükahmetler ${ }^{73}$ suggested that the effect of salinity on flower bud formation could be curvilinear, i.e. the plant can overcome and adjust to the salinity effect over time. Unfortunately, this assumption was not the case in this study and may be due to the short duration of the study. The suppression of plant growth under saline conditions may be associated with decreased availability of water or to the toxicity of sodium chloride. ${ }^{74}$ Furthermore, the hydrolysis of reserved foods to produce energy necessary for survival reduces the amount of resources available for flower formation. Salinity stress imposes additional energy requirements on plant cells and less carbon is available for growth and flower primordial initiation. ${ }^{6,65,74}$ Salinity effect on flower formation is likely an indirect result of its effect on photosynthesis (Pn) efficiency as well. Although Pn is less sensitive to salinity when compared to other growth parameters, ${ }^{47}$ it does add additional support to the superior salinity tolerance of G. flavum as compared to the other tested species. Previous studies documented the adverse effects of salinity on Pn in several species. ${ }^{25,27,28,75,76}$ In creeping bentgrass, Liu and Cooper ${ }^{76}$ reported a $20 \%$ decrease in Pn when salinity increased from 0.0 to $16 \mathrm{dS}$ m-1, while Qian and $\mathrm{Fu}^{25}$ reported a $40 \%$ decrease for the same species when salinity increased from control $(0.2 \mathrm{dS} \mathrm{m}-1)$ to $15 \mathrm{dSm}-1$. Increasing salinity and reduction in mowing heights of Bermudgrass ${ }^{27}$ cultivars and seashore paspalum cultivars ${ }^{28}$ additively decreased canopy photosynthesis. Photosynthetic capacity is reduced in the presence of high salinity due to stomata closure, damage to photosynthetic systems by excessive energy, structural disorganization or reduction in photochemical quenching. ${ }^{31,77}$

Razmjoo e al. ${ }^{65}$ has related the negative effects of salinity on flower number to its early effect on the growth and production of strong a shoot system. Pessarakli and Touchane ${ }^{78}$ found that the reduction in biomass production due to salinity stress is more obvious than the reduction in shoot lengths in bermudagrass. The decrease in plant biomass production due to salinity may be attributed to low or medium water potential, specific ion toxicity, or ion imbalance. ${ }^{4}$ In addition; elevated salinity may adversely affect photosynthesis and as a result adversely affect plant biomass production through less accumulation of carbon products. ${ }^{56}$

The reduction in the number of flowers usually is more drastic than other growth parameters under high salinity as it is a cumulative effect. ${ }^{65}$ High salinity in irrigation water has been reported to reduce flowering intensity, fruit set, number of fruits, and fruit growth. ${ }^{79-81}$ Flower yield of China aster was reduced from $49.8 \mathrm{~g} / \mathrm{plant}$ to 26.3 $\mathrm{g} /$ plant when salinity was increased from control to only $4 \mathrm{dSm}-1 .{ }^{73}$

\section{Plant quality (attractiveness)}

Plant quality (attractiveness) varied significantly among species and salinity levels. The interaction between species and salinity levels was significant too (Table 1). Plant quality decreased linearly with increasing salinity level in all species. Regressions were strongly linear, with slope more negative in the less tolerant species (Table 2). Increasing salinity decreased the attractiveness of all Glaucium spp. although to different degrees (Figure 7). Under the control treatment, there was no difference between G, flavum, and G. acutidenatum and both did equally well and achieved the maximum quality $(10,10)$, while there was a significant difference between G. grandflorum (9.5) and G. corniculatum (9) (Figure 7). The treatment of $5 \mathrm{dSm}-1 \mathrm{did}$ not have a significant effect on the quality of G. flavum, although it significantly reduced the quality of the other species (Figure 7). All species were adversely affected at the salinity level of $15 \mathrm{dS}$ m-1, where, G. flavum had a limited decline (9) followed by G. acutidetutum (8), G. grandiflorum (6.24) and G. corniclatum (5.5) (Figure 7). The decline in quality and attractiveness under the higher salinity level of $25 \mathrm{dS} / \mathrm{m}$ was more severe in all species; however, G. flavum had the 
highest quality at this level which indicates its relative superior salinity tolerance (Figure 7). The response of plants to salinity is determined by their general growth characteristics and by their physiological mechanisms of salt tolerance. The range of salinity in which the plant is able to survive varies according to the species; ${ }^{82}$ In several species growth may be affected by either the absence of or excess of $\mathrm{NaCl}$ in the substrate..$^{59,62,83-86}$ The ability to limit $\mathrm{Na}+$ transport into the shoots, and to reduce the $\mathrm{Na}+$ accumulation in the rapidly growing shoot tissues, is critically important for maintenance of high growth rates and protection of the metabolic process in elongating cells from the toxic effects of $\mathrm{Na}^{65}$ for example, the quality of lilies (plant height, flower bud length and flower diameter) decreased as salinity levels increased. ${ }^{73}$

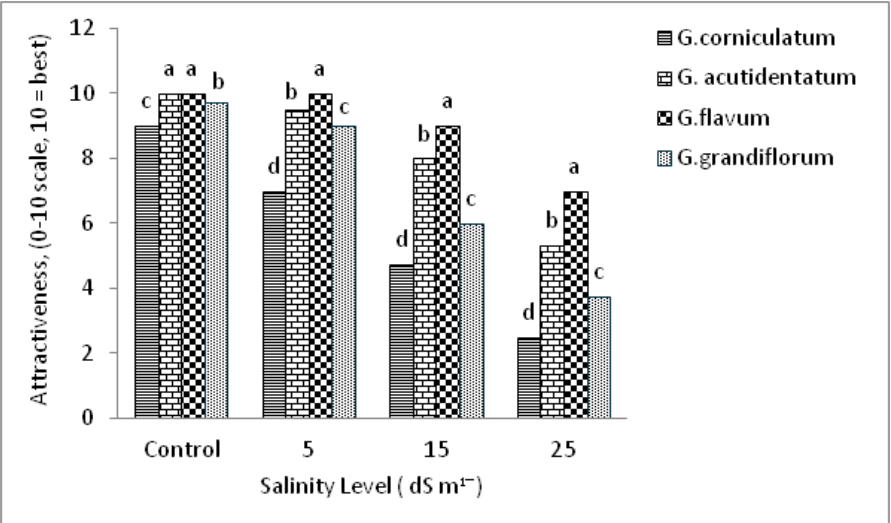

Figure 7 Effect of different salinity levels on the attractiveness of four Glaucium spp. Columns labeled with different letters are significantly different at $\mathrm{P}=0.05$ within each salinity level.

Salinity may directly or indirectly inhibit cell division and enlargement and finally the growth of the whole plant. Some above ground visible morphological symptoms of plants are marginal yellowing/browning of foliage, premature leaf fall, twig and branch die back, loss of vigor and stunted growth. ${ }^{45}$ Several previous studies indicated similar results to the findings on Horny poppy. Fu et al. ${ }^{47}$ indicated a decline in the turf quality of 'Brilliant' Kentucky bluegrass and 'L-93' creeping bentgrass irrigated with high salinity water when compared to those irrigated with fresh water. Salinity caused a decline in the quality of bermudagrass cultivars ${ }^{27}$ and in seashore paspalum cultivars. ${ }^{28}$ Razmjoo et al ${ }^{65}$ related the negative effects of salinity on plant quality to its early effect on the growth and production of a strong shoot system and as a result flowering ability. The reduction in biomass production due to salinity stress is more obvious than the reduction in shoot lengths in bermudagrass and more effective on the quality. ${ }^{78}$ The decrease in plant biomass production due to salinity may be attributed to low or medium water potential, specific ion toxicity, or ion imbalance. ${ }^{4}$ In addition, elevated salinity may adversely affect photosynthesis and as a result adversely affect plant biomass production through less accumulation of carbon products. ${ }^{56}$ The reduction in the number of flowers usually is more drastic than other growth parameters under high salinity as it is a cumulative effect. ${ }^{65}$ Fewer and smaller or weak flowers adversely affect the attractiveness of any landscape plant.

\section{Shoot total nonstructural carbohydrates and total reducing sugar content}

Shoot TNC varied significantly among species, salinity levels and their interaction (Table 1). Increasing salinity decreased shoot TNC of
Glaucium spp. (Table 3). Regression analysis indicated a significant negative linear relationship between salinity levels and TNC contents (Table 3). In G. flavum, as salinity levels increased from control to 5, 15 and $25 \mathrm{dS} \mathrm{m}-1$, average TNC decreased by $15.7,28.6$ and $43.6 \%$ and the average TNC decrease in G. acutidenatum shoots was 17.6, 36.8 and $48 \%$. The decrease in G. grandflorum was 20,40 and $48.6 \%$ while the decrease in G. corniculatum was $28.9,49$, and $53 \%$, respectively. A decline in TNC was recorded, most likely due to continued defoliation that removed photosynthetic tissues due to whole plant stress. High salinity escalated the reduction in TNC which resulted from the reduction in the shoot system. Shoot RSC varied significantly among species, salinity levels and their interactions (Table 1). RSC response to different salinity treatments followed a different trend than TNC (Table 4). Reducing sugars in plants mainly consists of glucose and fructose. ${ }^{87,88}$ While nonstructural carbohydrates are energy reserves in plants, soluble reducing sugars are thought to play an important role in salinity, drought and freezing tolerance as osmoregulators and as protectants as they prevent cell desiccation. ${ }^{89}$ Regression analysis indicated a significant positive association between salinity and RSC content in all species at all salinity levels (Table 4). As salinity levels increased from control to 5,15 and $25 \mathrm{dS}$ m-1, average RSC increased by 37,89 and $147 \%$ in G. flavum and by $17.2,43.8$ and $106 \%$ in G. acutidenatum. The increase was $15.1,26.3$, and $70.9 \%$ in G. grandflorum and 4, 23.3, and 61\% in G. corniculatum, respectively. Similar results were observed by Qian and $\mathrm{Fu}^{47}$ who found a decrease in TNC and an increase in RSC with increasing salinity level in shoots of L-93 creeping bentgrass. Shahba ${ }^{27}$ also found an increase in RSC and a decrease in TNC with increases salinity which was maximized at lower mowing heights in bermudagrass species (Tifgreen, Tifdwarf and (Tifway) and seashore paspalum cultivars. ${ }^{28}$ Carbon reduction could be related to the salt resistance mechanisms that are energy dependent. The results suggested that carbohydrate availability was a limiting factor for shoot growth under high salinity stress that results in shoot reduction.

Soluble carbohydrates may interact with membrane phospholipids and proteins to stabilize their structures and prevent desiccation under salinity stress ${ }^{89}$ In agreement with the horned poppy findings, Lee et al. ${ }^{23,24}$ reported a positive association between salinity tolerance and reducing sugars accumulation in seashore paspalums. Also, Qian and $\mathrm{Fu}^{25}$ indicated that salinity increased glucose and fructose content in bentgrass. TNC serves as the resource for the increased RSC under increased salinity conditions i.e. the relationship between TNC and $\mathrm{RSC}$ is a source sink relation.

\section{Shoot proline content}

Shoot proline content varied significantly among species, salinity levels and their interaction (Table 1). Increasing salinity increased shoot proline content of Glaucium species (Table 5). As salinity levels increased from control to 5, 15 and $25 \mathrm{dS} \mathrm{m}-1$, average Proline content in shoots increased by 218,367 , and $537 \%$ in G. flavum, 64.5, 296 and $510 \%$ in G. acutidenatum, 156, 273 and $428 \%$ in G. grandflorum, and 79,188 , and $337 \%$ in G. corniculatum, respectively. Regression analysis indicated a significant positive association between salinity and Proline content in all species (Table 5). Although the role of proline accumulation in salinity tolerance is well documented in this study, it has been questioned by others. ${ }^{34}$ These results suggested a positive role for proline in Glaucium species salinity tolerance. A positive effect of proline accumulation in salinity tolerance was also reported in seashore paspalum cultivars. ${ }^{27}$ Accumulation of proline in plant tissues in response to salinity stress has been attributed to 
enzyme stabilization and/or osmoregulation. ${ }^{8,11}$ It likely enhances membrane stability and mitigates the effect of $\mathrm{NaCl}$ on cell membrane disruption and protein structure, act as a sink for carbon and nitrogen for stress recovery and can buffer cellular redox potential under salinity stress. ${ }^{29}$ Maggio et al.$^{30}$ suggested that proline may act as a signaling/regulatory molecule able to activate multiple responses that participate in the adaptation process to elevated salinity levels.

Table 3 Total nonstructural carbohydrates (TNC) in shoots of Glaucium spp. measured at the end of the experiment vs. salinity levels, control (c), 5, I5, $25 \mathrm{dSm}{ }^{-1}$

\begin{tabular}{|c|c|c|c|c|c|c|}
\hline \multirow{3}{*}{ Species } & \multirow{2}{*}{\multicolumn{4}{|c|}{$\begin{array}{l}\text { TNC (mg g g-1 dry wt) } \\
\left.\text { Salinity level (dS } \mathbf{m}^{-1}\right)\end{array}$}} & \multirow{3}{*}{ Regression } & \multirow{3}{*}{$\mathbf{R}^{2}$} \\
\hline & & & & & & \\
\hline & C & 5 & 15 & 25 & & \\
\hline G. acutidentatum & $125.6 \mathrm{~b} \dagger$ & $103.8 \mathrm{~b}$ & $79.2 b$ & $65.2 b$ & $Y=|3| .|-| . \mid X$ & 0.91 ** \\
\hline G. corniculatum & $103.8 \mathrm{~d}$ & $79.7 d$ & $53.8 \mathrm{~d}$ & $49.2 d$ & $Y=119.1-1.2 X$ & $0.92^{* *}$ \\
\hline G. flavum & $133.2 \mathrm{a}$ & $112.2 \mathrm{a}$ & $95.5 \mathrm{a}$ & $74.9 \mathrm{a}$ & $Y=116.6-0.9 X$ & $0.89 * *$ \\
\hline G. grandiflorum & $109.9 c$ & $88.2 \mathrm{c}$ & $66.5 \mathrm{c}$ & $56.5 c$ & $Y=125.5-1.2 X$ & $0.82^{* *}$ \\
\hline
\end{tabular}

†Values followed by the same letters within a column for each cultivar are not significantly different $(P=0.05)$ based on a Fisher's LSD test.

*Significant at $P 0.05$.

** Significant at $P 0.01$

Table 4 Total reducing sugar content (RSC) in shoots of Glaucium spp. measured at the end of the experiment vs. salinity levels, Control (c), 5, 15, $25 \mathrm{dSm}{ }^{-1}$

\begin{tabular}{|c|c|c|c|c|c|c|}
\hline \multirow{3}{*}{ Species } & \multirow{2}{*}{\multicolumn{4}{|c|}{$\begin{array}{l}\text { RSC (mgg }{ }^{-1} \text { dry wt) } \\
\text { Salinity level }\left(d^{-1} m^{-1}\right)\end{array}$}} & \multirow{3}{*}{ Regression } & \multirow{3}{*}{$\mathbf{R}^{2}$} \\
\hline & & & & & & \\
\hline & c & 5 & 15 & 25 & & \\
\hline G. acutidentatum & 19.2 & $22.5 b \dagger$ & $27.6 b$ & $39.6 b$ & $Y=21.7+0.12 X$ & $0.82 * *$ \\
\hline G. corniculatum & 15.9 & $16.6 \mathrm{~d}$ & $19.6 d$ & $25.6 \mathrm{~d}$ & $Y=16.3+0.11 X$ & $0.72^{*}$ \\
\hline G. flavum & 18.9 & $25.9 \mathrm{a}$ & $35.8 \mathrm{a}$ & $46.8 \mathrm{a}$ & $Y=11.5+0.30 X$ & $0.92 * *$ \\
\hline G. grandiflorum & 17.9 & $20.6 c$ & $22.6 \mathrm{cb}$ & $30.6 c$ & $Y=16.3+0.15 X$ & $0.79 *$ \\
\hline
\end{tabular}

† Values followed by the same letters within a column for each cultivar are not significantly different $(P=0.05)$ based on a Fisher's LSD test. *Significant at $P \leq 0.05$.

** Significant at $P 0.01$.

Table 5 Proline content in shoots of Glaucium spp. measured at the end of the experiment vs. salinity levels, Control (c), 5, 15, 25dSm ${ }^{-1}$

\begin{tabular}{|c|c|c|c|c|c|c|}
\hline \multirow{3}{*}{ Species } & \multicolumn{4}{|c|}{ Proline content $\left(\mu g^{-1}\right.$ fresh $\left.w t\right)$} & \multirow{3}{*}{ Regression } & \multirow{3}{*}{$\mathbf{R}^{2}$} \\
\hline & \multicolumn{4}{|c|}{ Salinity level $\left(\mathrm{dSm}^{-1}\right)$} & & \\
\hline & c & 5 & 15 & 25 & & \\
\hline G. acutidentatum & 250.0 & $646.0 \mathrm{~b} \dagger$ & $990.0 \mathrm{~b}$ & $1527.0 \mathrm{~b}$ & $Y=218.3+22.9 X$ & $0.87^{* *}$ \\
\hline G. corniculatum & 233.7 & $418.0 d$ & $670.0 d$ & $1018.0 \mathrm{~d}$ & $Y=150.7+19.7 X$ & $0.77^{*}$ \\
\hline G. flavum & 268.7 & $855.0 \mathrm{a}$ & $1255.0 \mathrm{a}$ & $1712.0 \mathrm{a}$ & $Y=142.4+12.6 X$ & $0.92 * *$ \\
\hline G. grandiflorum & 230.6 & $590.0 c$ & $860.0 c$ & $1215.0 \mathrm{c}$ & $Y=189+20.7 X$ & $0.81^{*}$ \\
\hline
\end{tabular}

†Values followed by the same letters within a column for each cultivar are not significantly different $(P=0.05)$ based on a Fisher's LSD test. *Significant at $P \leq 0.05$.

$* *$ Significant at $P \leq 0.01$.

\section{Shoot and root $\mathrm{K}+/ \mathrm{Na}+$ ratio}

Shoot and root $\mathrm{K}+$ and $\mathrm{Na}+$ varied significantly among species, salinity levels and their interaction (Table 1). Increasing salinity decreased shoot $\mathrm{K}+/ \mathrm{Na}+$ ratio (Table 6 ). As salinity increased, $\mathrm{Na}+$ content increased and $\mathrm{K}+$ content decreased. Regression analysis indicated a significant negative linear relationship between salinity levels and $\mathrm{K}+/ \mathrm{Na}+$ ratios (Table 6). Wyn Jones et al. ${ }^{90}$ suggested a threshold $\mathrm{K}+\mathrm{Na}+$ ratio of 1 for normal growth of plants subjected to salinity. Results indicated that $\mathrm{K}+\mathrm{Na}+$ ratio was $\geq 1$ at all salinity levels in G. flavum, as compared to G. acutidenatum, G. grandflorum and G. corniculatum (Table 3). Similar results were reported by Qian and $\mathrm{Fu},{ }^{25}$ who studied the response of creeping bentgrass, Shahba, ${ }^{27}$ who studied the response of bermudagrass cultivars to salinity and mowing heights and Shahba et al. ${ }^{28}$ who studied the response of seashore paspalum cultivars to salinity and mowing heights, there was an increase in $\mathrm{Na}+$ and a decrease in $\mathrm{K}+$ concentration in shoots 
with increasing salinity level, this was more obvious at higher salinity levels where a reduction in shoot size was observed. Storey and Wyn Jones ${ }^{90}$ suggested that the capacity to maintain high shoot $\mathrm{K}+/ \mathrm{Na}+$ ratios is an important element of salt tolerance, especially in species which lack foliar salt-excretion mechanisms such as Glaucium species. Shannon ${ }^{91}$ studied salt tolerance of 32 lines of tall wheatgrass and found an association between salinity tolerance and the maintenance of $\mathrm{K}+\mathrm{Na}+$ ratio $\geq 1$. This suggested that the increase in mowing height may help limit shoot $\mathrm{Na}+$ and improve $\mathrm{K}+$ concentrations in the shoot. Also, it has been demonstrated that salinity tolerance in several grass species (Poaceae) is associated with the exclusion of $\mathrm{Na}+$ from shoot and the capacity to maintain high shoot $\mathrm{K}+/ \mathrm{Na}+$ ratio. ${ }^{27,28,33,47,92,93}$ Greive et al. ${ }^{94}$ found an increase in $\mathrm{Na}+$ concentration and a decrease in $\mathrm{K}+$ ion concentration when salinity increased from 15 to $25 \mathrm{dS} \mathrm{m}-1$ and concluded that neither $\mathrm{K}+/ \mathrm{Na}+$ ratios nor $\mathrm{K}+: \mathrm{Na}+$ selectivity coefficients appear to be satisfactory indicators of relative salt tolerance of the forages examined in their study. Similarly, Lee et al. ${ }^{23}$ concluded that $\mathrm{K}+\mathrm{Na}+$ ratio did not appear to be related to salinity tolerance of seashore pasplaum ecotypes.

Table 6 Effect of different salinity levels on $\mathrm{K}+/ \mathrm{Na}+$ ratio of Glaucium spp. linear regression of different $\mathrm{K}+/ \mathrm{Na}+$ ratios of measured at the end of the experiment vs. salinity levels, Control (c), 5, 15, $25 \mathrm{dSm}^{-1}$

\begin{tabular}{|c|c|c|c|c|c|c|}
\hline \multirow{3}{*}{ Species } & \multicolumn{4}{|c|}{$\mathrm{K}^{+} / \mathrm{Na}^{+}$ratio } & \multirow{3}{*}{ Regression } & \multirow{3}{*}{$\mathbf{R}^{2}$} \\
\hline & \multicolumn{4}{|c|}{ Salinity level (dS m $^{-1}$ ) } & & \\
\hline & C & 5 & 15 & 25 & & \\
\hline G. acutidentatum & $2.8 \mathrm{~b}$ & 2.16 & $1.1 \mathrm{~b}$ & $0.6 \mathrm{~b}$ & $Y=\mid 28.0-0.91 X$ & $0.77^{*}$ \\
\hline G. corniculatum & $2.0 \mathrm{~d}$ & $1.3 \mathrm{~d}$ & $0.5 \mathrm{~d}$ & $0.2 c$ & $Y=\mid 12.4-1.1 X$ & $0.84 * *$ \\
\hline G. flavum & $3.2 \mathrm{a}$ & $2.5 \mathrm{a}$ & $1.5 \mathrm{a}$ & $1.0 \mathrm{a}$ & $Y=121.1-1.66 X$ & $0.82^{* *}$ \\
\hline G. grandiflorum & $2.4 \mathrm{c}$ & $1.7 \mathrm{c}$ & $0.7 c$ & $0.3 c$ & $Y=|2| .7-1.65 X$ & $0.82^{* *}$ \\
\hline
\end{tabular}

†Values followed by the same letters within a column for each cultivar are not significantly different $(P=0.05)$ based on a Fisher's LSD test. *Significant at P0.05.

** Significant at P0.0I

The proteins of the cell membrane play a significant role in the selective distribution of ions within the plant cells. These proteins include 1) Primary $\mathrm{H}+$-ATPases that generate the $\mathrm{H}+$ electrochemical gradient. This gradient controls ion transport through the plasma membrane with high selectivity for $\mathrm{K}+$ over $\mathrm{Na}+$, 2) $\mathrm{K}+/ \mathrm{Na}+$ antiports in the plasma membrane for pumping excess $\mathrm{Na}+$ out of the cell, 3) $\mathrm{Na}+/ \mathrm{H}+$ antiports in the tonoplast for extruding $\mathrm{Na}+$ into the vacuole. ${ }^{34,95}$ The selectivity of $\mathrm{K}+$ over $\mathrm{Na}+$ in root uptake is an energy dependent process and more likely regulated to a substantial degree by $\mathrm{H}+$ gradients across the plasma membrane which are maintained by $\mathrm{H}+$-ATP ase activity. Low mowing height depletes TNC reserves which induce ATP deficit, resulting in the lack of energy to control active ion selectivity in uptake and transport. . $5,27,28^{2}$

Salt stress responses are tissue- and salinity-specific. For longterm performance and persistence in field situations under salt stress, it is essential that grasses exhibit both root and shoot tissue salinity tolerance. $^{2}$ On the basis of the number of times in the best statistical category for leaf characteristics, plant height, flowering characteristics, overall plant quality (attractiveness), TNC, RSC, proline content and $\mathrm{K}+/ \mathrm{Na}+$ ratio, $\mathrm{G}$. flavum was found to have higher salt tolerance when compared to G. acutidenatum, G. grandflorum and G. corniculatum. Also, increasing salinity had less adverse effects on overall responses of all species when they were able to maintain a larger shoot system.

In summary, as salinity increased, Glaucium spp. exhibited reduction in leaf characteristics, plant height, flowering characteristics, overall plant quality (attractiveness), $\mathrm{TNC}$, and $\mathrm{K}+\mathrm{Na}+$ ratio, and increased shoot total reducing sugars and proline content. G. flavum showed greater salinity tolerance at all salinity levels when compared to the other species tested. Proline accumulation could add to the salinity tolerance through osmoregulation or by acting as carbon and nitrogen sink for stress recovery.

\section{Acknowledgments}

None.

\section{Conflicts of interest}

Authors declare that there is no conflict of interest.

\section{References}

1. Rameeh V, A Cherati, F Abbaszadeh. Relationship between seed yield and shoot ions at vegetative and reproductive stages of rapeseed genotypes under saline environment. International Journal of Plant Research. 2012;2:(3):61-64.

2. Carrow RN, RR Duncan. Salt-aff ected turfgrass sites: assessment and management. Wiley, Hoboken; 1998.

3. Marcum KB, SJ Anderson, MC Engelke. Salt gland ion secretion: A salinity tolerance mechanism among five zoysiagrass species. Crop Science. 1998;38(3):806-810.

4. Greenway H, R Munns. Mechanisms of salt tolerance in non-halophytes. Annu Rev Plant Physiol. 1980;31:149-190.

5. Lauchli A. Responses and adaptation of crops to salinity. Acta Hortic. $1986 ; 190: 243-246$

6. Cheeseman JM. Mechanisms of salinity tolerance in plants. Plant Physiol. 1988;87:745-755.

7. Brugnoli E, O Bjorkman. Growth of cotton under continuous salinity stress: Influence on allocation pattern, stomatal and non-stomatal components of photosynthesis and dissipation of excess light energy. Planta. 1992;187:335-347.

8. Flowers T, E Duque, MA Hajibagheri, et al. The effect of salinity on leaf ultrastructure and net photosynthesis of two varieties of rice: Further evidence for a cellular component of salt-resistance. New Phytol. $1985 ; 100: 37-43$ 
9. Delfine S, A Alvino, M Zacchini, et al. Consequences of salt stress on conductance to $\mathrm{CO} 2$ diff usion, Rubisco characteristics and anatomy of spinach leaves. Aust J Plant Physiol. 198;25:395-402.

10. Romero AR, JL Moya, FR Tadeo, et al. Physiological and anatomical disturbances induced by chloride salts in sensitive and tolerant citrus: Benefi cial and detrimental effects of cations. Plant Cell Environ. 1998;21:1243-1253.

11. Levitt J. Salt stresses. In responses of plants to environmental stresses. Academic press. London; 1980(2);365-454.

12. Harivandi MA, JD Butler, L Wu. Salinity and turfgrass culture. In: DV Waddington, editors, Turfgrass. Agron. Monogr. ASA, Madison, WI. 1992;208-230.

13. Epstein E, JD Norlyn, DW Rush, et al. Saline culture of crops: A genetic approach. Science. 1980;210:399-404.

14. Pasternak D. Salt tolerance and crop production: A comprehensive approach. Annu Rev Phytopathol. 1987;25:271-291.

15. Saranga Y, A Cahaner, D Zamir, et al. Breeding tomatoes for salt tolerance and related traits in interspecific populations. Theor Appl Genet. 1992;84:390-396.

16. Shannon MC. Principles and strategies in breeding for higher salt tolerance. Plant Soil. 1985;89:227-241.

17. Bohnert HJ, DE Nelson, RG Jensen. Adaptation to environmental stress. Plant Cell. 1995;7:1099-1111.

18. Igartua, E. Choice of selection environment for improving crop yields in saline areas. Theor Appl Genet. 1995;91:1016-1021.

19. Duncan RR, RN Carrow. Turfgrass molecular genetic improvement for biotic/edaphic stress resistance. Adv Agron. 1999;67:233-305.

20. Grey-Wilson C. Poppies: a guide to the poppy family in the wild and in cultivation. Timber Press, Portland; 2000.

21. Davis PH. Flora of turkey and east aegean islands. Edinburg: Edinburgh University; 1965-1985. p. 1-9.

22. Huang BR, JD Fry. The importance of carbon balance and root activity in creeping bentgrass tolerance to summer stresses. Agric Experiment Stn. Annu Project Rep. Kansas State Univ. Manhattan.

23. Lee GJ, RN Carrow, RR Duncan. Identification of new soluble sugars accumulated in a halophytic Seashore paspalum ecotype under salinity stress. Hortic Environ Biotechnol. 2008;49(1):13-19.

24. Lee GJ, RN Carrow, RR Duncan, et al. Synthesis of organic osmolytes and salt tolerance mechanisms in Paspalum vaginatum. Environ Exp Bot 2008b;63(1-3):19-27.

25. Qian YL, JM Fu. Response of creeping bentgrass to salinity and mowing management: Carbohydrate availability and ion accumulation. Hort Science. 2005;40:2170-2174.

26. Lee GJ, RR Duncan, RN Carrow. Nutrient uptake responses and inorganic ion contribution to solute potential under salinity stress in halophytic seashore paspalum. Crop Sci. 2007;47:2504-2512.

27. Shahba MA. Interaction effects of salinity and mowing on performance and physiology of bermudagrass cultivars. Crop Sci. 2010b;50:2620 2631.

28. Shahba MA, SF Alshammary, MS Abbas. Effects of salinity on seashore paspalum cultivars at different mowing heights. Crop Science. 2012; $52 ;(3): 1358-1370$

29. Ashraf M, MR Foolad. Role of glycine betaine and proline in improving plant abiotic stress resistance. Environ Exp Bot. 2007;59:206-216.
30. Maggio A, S Miyazaki, P Veronese, et al. Does proline accumulation play an active role in stress induced growth reduction?. Plant J. 2002;31:699712 .

31. Flowers TJ, PF Troke, AR Yeo. The mechanism of salt tolerance in halophytes. Annu Rev Plant Physiol. 1977;28:89-121.

32. Ahmad I, SJ Wainwright, GR Stewart. The solute and water relations of Agrostis stolonifera ecotypes differing in their salt tolerance. New Phytol. 1981;87:615-628.

33. Torello WA, LA Rice. Effects of $\mathrm{NaCl}$ stress on proline and cation accumulation in salt sensitive and tolerant turfgrasses. Plant Soil. 1986;93:241-247.

34. Ashraf M, PJC Harris. Potential biochemical indicators of salinity tolerance in plants. Plant Sci. 2004;166:3-16.

35. Chatterton NJ, JH Bennett, WR Thornley. Fructan, starch and sucrose concentrations in crested wheatgrass and redtop as affected by temperature. Plant Physiol Biochem. 1987;25:617-623.

36. Bates LS, RP Waldren, ID Teare. Rapid determination of free proline for water stress studies. Plant Soil. 1973;39:205-207.

37. SAS Institute. SAS/STAT user's guide. SAS Institute, Cary; 2006.

38. Bayat H, M Alirezaie, H Neamati. Impact of exogenous salicylic acid on growth and ornamental characteristics of calendula (Calendula officinalis L.) under salinity stress. Journal of Stress Physiology \& Biochemistry. 2012;8(1):258-267.

39. Choi K, Y Lee. Effect of salinity of nutrient solution on growth, translocation and accumulation of $45 \mathrm{Ca}$ in butterhead lettuce. In International Symposium on Growing Media and Hydroponics. 1999;548:575-580

40. Kubis S, R Patel, J Combe, et al. Functional specialization amongst the arabidopsis Toc159 family of chloroplast protein import receptors. The Plant Cell Online. 2004;16(8):2059-2077.

41. Murkute AA, Sharma S, Singh SK. Studies on salt stress tolerance of citrus rootstock genotypes with arbuscular mycorrhizal fungi. Horticulture Science. 2006;33:70-76.

42. Jaleel CA, B Sankar, R Sridharan, et al. Soil salinity alters growth, chlorophyll content, and secondary metabolite accumulation in Catharanthus roseus. Turk J Biol. 2008;32:79-83.

43. Parida AK, AB Das. Salt tolerance and salinity effects on plants: a review. Ecotoxicology and environmental safety. 2005;60(3):324-349.

44. El-Desouky SA, AAR Atawia. Growth perfomance of citrus rootstocks under saline conditions. Alexandria Journal of Agricultural Research. 1998;43:231-254.

45. Aggarwal A, N Kadian, N Karishma, et al. Arbuscular mycorrhizal symbiosis and alleviation of salinity stress. Journal of Applied and Natural Science. 2012;4(1):144-155.

46. Enteshari S, S Hajbagheri. Effects of mycorrhizal fungi on some physiological characteristics of salt stressed Ocimun basillicum L. Iranian J Plant Physiol. 2011;1:215-222.

47. Fu JM, AJ Koski, YL Qian. Responses of creeping bentgrass to salinity and mowing management: Growth and turf quality. HortScience. 2005;40:463-467.

48. Francois LE. Salinity eff ects on three turf bermudagrasses. HortScience. 1988;23:706-708.

49. Dudeck AE, S Singh, CE Giordano, et al. Effects of sodium chloride on Cynodon turfgrasses. Agron J. 1983;75:927-930. 
50. Marcum KB, CL Murdoch. Growth responses, ion relations and osmotic adaptations of eleven C4 turfgrasses to salinity. Agron J. 1990;82:892896.

51. Shahba MA. Comparative responses of bermudagrass and seashore paspalum cultivars commonly used in Egypt to combat salinity stress. $J$ Hortic Environ Biotech. 2010a;51:383-390.

52. Marcum KB. Salinity tolerance of 35 bentgrass cultivars. HortScience. 2001;36:374-376.

53. Jaleel CA, Gopi R, Manivannan P, et al. Responses of antioxidant defense system of Catharanthusroseus (L.) G. Don. to paclobutrazol treatment under salinity. Acta Physiologiae Plantarum. 2007;29(3):205-209.

54. Munns R, A Gardner, ML Tonnet, et al. Growth and development in $\mathrm{NaCl}$-treated plants. II. Do $\mathrm{Na} 2$ or $\mathrm{Cl} 2$ concentrations in dividing or expanding tissues tissues determine growth in barley?. Aust J Plant Physiol. 1988;15:529-540.

55. Volkmar KM, Y Hu, H Steppuhn. Physiological responses of plants to salinity: a review. Can J Plant Sci. 1998;78:19-27.

56. Munns R, A Termatt. Whole-plant responses to salinity. Aust J Plant Physiol. 1986;13:143-160.

57. Chartzoulakis K, G Klapaki. Response of two greenhouse pepper hybrids to $\mathrm{NaCl}$ salinity during different growth stages. Scientia Horticulturae. 2000;86(3):247-260

58. Dagar JC, H Bhagwan, Y Kumar. Effect on growth performance and biochemical contents of Salvadora persica when irrigated with water of different salinity. Indian Journal of Plant Physiology. 2004;9:234-238.

59. Clough BF. Growth and salt balance of the mangroves Avicennia marina (Forsk.) Vierh. and Rhizophora stylosa Griff. In relation to salinity. Aust J Plant Physiol. 1984;11:419-430

60. Srivastava DS, RL Jefferies. The effect of salinity on the leaf and shoot demography of two arctic forage species. J Ecol. 1995; 83:421-430.

61. Warwick NWM, PCE Bailey. The effect of time of exposure to $\mathrm{NaCl}$ on leaf demography and growth for two non-halophytic wetland macrophytes, Potamogeton tricarinatus F Muell and A Benn ex A. Benn and Triglochin procera R. Br. Aquat Bot. 1988;62:19-31.

62. Suárez N, E Medina. Salinity effect on plant growth and leaf demography of the mangrove, Avicennia germinans L. Trees. 2005;19 (6):722-728.

63. Munns R, M Tester. Mechanisms of salinity tolerance. Annu Rev Plant Biol. 2008;59:651-681.

64. Ungar IA. Effect of salinity on seed germination, growth, and ion accumulation of Atriplex patula (Chenopodiaceae). American Journal of Botany. 1996;604-607.

65. Razmjoo K, P Heydarizadeh, MR Sabzalian. Effect of salinity and drought stresses on growth parameters and essential oil content of Matricaria chamomile. Int J Agric Biol. 2008;10(4):451-454.

66. Bybordi A. Effects of salinity on yield and component characters in canola (Brassica napus L.) cultivars. Notulae Scientia Biologicae. 2010;2(1):81-83.

67. Dumbroff EB, A Cooper. Effects of salt stress applied in balanced nutrient solutions at several stages during growth of tomato. Bot Gaz. 1974; 135:219-224.

68. Marcum KB. Salinity tolerance in turfgrasses. In: M Pessarakli, editor, Handbook of plant and crop stress. Marcel Dekker, New York.1999;891905

69. Peacock $\mathrm{CH}, \mathrm{AE}$ Dudeck. Physiological and growth responses of seashore paspalum to salinity. HortScience. 1985;20:111-112.
70. Rozema J, M Visser. The applicability of the rooting technique measuring salt resistance in populations of Festuca rubra and Juncus species. Plant Soil. 1981;62:479-485.

71. Berkheimer SF, E Hanson. Deicing salts reduce cold hardiness and increase flower bud mortality of highbush blueberry. Journal of the American Society for Horticultural Science. 2006;131(1):11-16.

72. Falcón MF, CE González, V Garcia, et al. The effect of chloride and bicarbonate levels in irrigation water on nutrition content, production and quality of cut roses 'Mercedes'. Scientia horticulturae. 1986;29(4):373385 .

73. Küçükahmetler $O$. The effects of salinity on yield and quality of ornamental plants and cut flowers. Acta Horticulturae (ISHS) 2002;573:407-414

74. Munns R. Comparative physiology of salt and water stress. Plant Cell Environ. 2003;25:239-250.

75. Chartzoulakis K, M Loupassaki, M Bertaki, et al. Effects of $\mathrm{NaCl}$ salinity on growth, ion content and $\mathrm{CO}_{2}$ assimilation rate of six olive cultivars. Sci Hortic. 2002;96:235-247.

76. Liu C, RJ Cooper. Humic acid application does not improve salt tolerance of hydroponically grown creeping bentgrass. J Am Soc Hortic Sci. 2002;127:219-223.

77. Lee GJ, RR Duncan, RN Carrow. Salinity tolerance of Seashore paspalum ecotypes: Shoot growth responses and criteria. HortScience 2004c;39:1143-1147.

78. Pessarakli $\mathrm{M}, \mathrm{H}$ Touchane. Growth responses of bermudagrass and seashore paspalum under various levels of sodium chloride stress. J Food Agric Environ. 2006;4:240-243.

79. Cole PJ, PI McLeod. Salinity and climatic effects on the yield of citrus. Aust J Exp Agric. 1985;25:711-717.

80. Howie HJ, Lloyd J. Response of orchard 'Washington navel' orange, Citrus sinensis (L.) Osbeck to saline irrigation water. 2. Flowering, fruit set and fruit growth. Aust J Agric Res. 1989;40:371-380.

81. Iglesias DJ, M Cercós, JM Colmenero-Flores, et al. Physiology of citrus fruiting. Brazilian Journal of Plant Physiology. 2007;19(4): 333-362.

82. Ball MC. Salinity tolerance in the mangroves Aegiceras corniculatum and Avicennia marina. I. Water use in relation to growth, carbon partitioning, and salt balance. Aust J Plant Physiol. 1988;15:447-464.

83. Downton WJS. Growth and osmotic relation of the mangrove Avicennia marina as influenced by salinity. Aust J Plant Physiol. 1982; 9:519-528.

84. Burchett MD, CJ Clarke, CD Field, et al. Growth and respiration in two mangrove species at a ranges of salinities. Physiol Plant. 1989;75:299 303.

85. Pezeshki SR, RD De Laune, W Patrick. Differential response of selected mangroves to soil flooding and salinity: gas exchange and biomass partitioning. Can J For Res. 1990;20:869-874.

86. Ball MC, SM Pidsley. Growth responses to salinity in relation to distribution of two mangrove species, Sonneratia alba and S. lanceolata in northern Australia. Funct Ecol. 1995;9:77-85.

87. Ball S, YL Qian, C Stushnoff. Soluble carbohydrates in two buff alograss cultivars with contrasting freezing tolerance. HortScience. 2002;127:4549.

88. Shahba MA, YL Qian, HG Hughes, et al. Relationship of carbohydrates and cold hardiness in six saltgrass accessions. Crop Sci. 2013;43:21482153.

89. Popp M, N Smirnoff. Polyol accumulation and metabolism during water deficit. In: N Smirnoff, editor, Environment and plant metabolism. 
Flexibility and acclimation. Bios Scientific, Oxford;1995;199-215.

90. Wyn Jones RG, CJ Brady, J Speirs. Ionic and osmotic relations in plant cells. In: DL. Laidman, RG Wyn Jones, editors, Recent advances in the biochemistry of cereals. Academic Press, London; 1979;63-103.

91. Shannon MC. Testing salt tolerance variability among tall wheatgrass lines. Agron J. 1978;70:719-722.

92. Qian YL, MC Engelke, MJV Foster. Salinity eff ects on zoysiagrass cultivars and experimental lines. Crop Sci. 2000;40:488-492.

93. Qian YL, SJ Wilhelm, KB Marcum. Comparative responses of two Kentucky bluegrass cultivars to salinity stress. Crop Sci. 2001;41:18951900.
94. Grieve CM, JA Possb, SR Grattana, et al. Evaluation of salt-tolerant forages for sequential water reuse systems. II. Plant-ion relations. Agric Water Manage. 2004;70:121-135.

95. Tester $\mathrm{M}, \mathrm{R}$ Davenport. $\mathrm{Na}+$ tolerance and $\mathrm{Na}+$ transport in higher plants. Ann Bot. 2003;91:503-527.

96. Storey R, RG Wyn Jones. Reponses of Atriplex spongiosa and Suaeda monoica to salinity. Plant Physiol. 1979;63:156-162. 